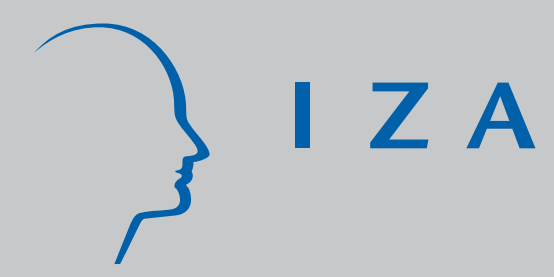

IZA DP No. 2282

The Labor Market Costs of Conflict:

Closures, Foreign Workers, and

Palestinian Employment and Earnings

Sami H. Miaari

Robert M. Sauer

September 2006 


\title{
The Labor Market Costs of Conflict: Closures, Foreign Workers, and Palestinian Employment and Earnings
}

\author{
Sami H. Miaari \\ World Bank West Bank and Gaza Office \\ and Hebrew University of Jerusalem
}

Robert M. Sauer

University of Southampton

and IZA Bonn

Discussion Paper No. 2282

September 2006

\author{
IZA \\ P.O. Box 7240 \\ 53072 Bonn \\ Germany \\ Phone: +49-228-3894-0 \\ Fax: +49-228-3894-180 \\ Email: iza@iza.org
}

Any opinions expressed here are those of the author(s) and not those of the institute. Research disseminated by IZA may include views on policy, but the institute itself takes no institutional policy positions.

The Institute for the Study of Labor (IZA) in Bonn is a local and virtual international research center and a place of communication between science, politics and business. IZA is an independent nonprofit company supported by Deutsche Post World Net. The center is associated with the University of Bonn and offers a stimulating research environment through its research networks, research support, and visitors and doctoral programs. IZA engages in (i) original and internationally competitive research in all fields of labor economics, (ii) development of policy concepts, and (iii) dissemination of research results and concepts to the interested public.

IZA Discussion Papers often represent preliminary work and are circulated to encourage discussion. Citation of such a paper should account for its provisional character. A revised version may be available directly from the author. 


\section{ABSTRACT \\ The Labor Market Costs of Conflict: Closures, Foreign Workers, and Palestinian Employment and Earnings}

In this paper, we measure the implications of the Israeli-Palestinian conflict for Palestinian employment and earnings. We quantify the conflict by the frequency of temporary closures of the West Bank and Gaza Strip and the number of overseas foreign workers in the Israeli labor market. Data on Palestinian employment and earnings are taken from the Palestinian Labor Force Survey (PLFS) of the Palestinian Central Bureau of Statistics. The PLFS micro level panel data are combined with quarterly time series data on the number of foreign workers in Israel, the number of foreign worker permits issued by the Israeli government, and the frequency of temporary closures of the West Bank and Gaza Strip, between the years 1999 and 2004. Fixed-effects estimates which exploit the number of foreign worker permits issued by the Israeli government as an instrument for the number of foreign workers, yield large and statistically significant negative effects of the Israeli-Palestinian conflict on Palestinian employment rates in Israel and mean monthly earnings, regardless of work location (Israel or West Bank and Gaza Strip). Closures also significantly reduce Palestinian employment rates in Israel and mean monthly earnings. The impact of foreign workers is relatively stronger than the impact of closures because foreign workers are long-run substitutes for Palestinians in the Israeli labor market while closures represent only a transitory, short-run restriction on Palestinian labor supply. However, the impact of foreign workers also reflects a permanent effect of closures.

JEL Classification: J21, J31, J40, J61, F22, C23

Keywords: conflict, immigration, Palestinians, Israelis, foreign workers, closures, employment, earnings, instrumental variables, panel data

Corresponding author:

Robert M. Sauer

School of Social Sciences

University of Southampton

Southampton SO17 1BJ

United Kingdom

E-mail: R.M.Sauer@soton.ac.uk 


\section{Introduction}

The economic costs of political conflict have long been a subject of great interest to economists. The large number of papers in this area offer ample empirical evidence that political instability has important economic consequences. However, most of the leading studies tend to focus on the implications of political instability for macroeconomic variables such as savings, investment and growth rates (see, e.g., Venieris and Gupta (1986), Barro (1991), Mauro (1995), Alesina and Perotti (1996), Abadie and Gardeazabal (2003), and Eckstein and Tsiddon (2004)). Relatively few papers analyze the effects of conflict on individual outcomes in particular markets, such as the labor market. ${ }^{1}$

In this paper, we contribute to the literature on the economic costs of political instability by measuring the implications of the Israeli-Palestinian conflict for Palestinian employment and earnings. ${ }^{2}$ We quantify the conflict by the frequency of closures of the West Bank and Gaza Strip and the number of overseas foreign workers in the Israeli labor market. The number of foreign workers is related to the conflict, in addition to closures, because the importation of foreign workers is believed to have been a way for Israel to reduce its traditional reliance on Palestinian labor. The Israeli government dramatically increased its issuance of foreign worker permits to Israeli employers starting in the mid 1990s.

\footnotetext{
${ }^{1}$ A notable exception is Angrist and Kugler (2004), who analyze the consequences of a shift in the drug trade (and related violence) on the income of the self-employed and the labor supply of teenage boys in Columbia.

${ }^{2}$ Other economic and political consequences of the Israeli-Palestinian conflict are examined in Berman and
} 
Measuring the consequences of closures and foreign workers for Palestinian labor market outcomes is accomplished by using unique micro level panel data from the Palestinian Labor Force Survey (PLFS) of the Palestinian Central Bureau of Statistics (PCBS). Data from the PLFS is combined with quarterly time series data on the number of foreign workers in Israel, and the frequency of temporary closures of the West Bank and Gaza Strip, between the years 1999 and 2004. Because the number of foreign workers in Israel in each quarter is likely to be endogenous, due to nonrandom immigration, we also compile quarterly data on the number of foreign worker permits issued by the Israeli government and use it as an instrument for the number of foreign workers in the Israeli labor market in each quarter.

The number of foreign worker permits issued by the Israeli government is likely to be a credible source of exogenous variation in the number of foreign workers employed or searching for work in the Israeli labor market each quarter because of the lags and inefficiencies in the regulatory process that governs the issuance of permits. Lags and inefficiencies create a situation whereby the number of permits issued in each quarter is not a direct result of contemporaneously rising wages or falling unemployment in Israel or its surrounding areas. We do not instrument for temporary closures of the West Bank and Gaza Strip since closures are mostly a consequence of surges in the IsraeliPalestinian conflict that have little to do with the unobserved determinants of Palestinian labor demand (see Angrist (1996)).

Exploiting the panel aspect of the PLFS and using the number of foreign workers permits

Laitin (2005), Berrebi and Klor (2005), and Jaeger and Paserman (2005). 
issued each quarter by the Israeli government as an instrument for the number of foreign workers, fixed-effects estimates yield large and statistically significant effects of the conflict on Palestinian employment rates in Israel and mean monthly earnings. The proportion of Palestinians from the West Bank that work in Israel is reduced by 8.6 percentage points for every 10,000 foreign workers present in the Israeli labor market. This implies that an increase of $10 \%$ in the supply of foreign workers, or a one standard deviation increase in supply, reduces the employment rate of Palestinians from the West Bank in Israel by 17.2 percentage points. The same increase in the supply of foreign workers reduces the employment rate of Palestinians from Gaza in Israel by 12.4 percentage points. The overall reduction in the Palestinian employment rate in Israel thus reaches 30 percentage points. Fixed-effects estimates also indicate that an increase of one standard deviation in the supply of foreign workers reduces the mean monthly earnings of Palestinians that reside in the West Bank by $10.6 \%$ and reduces the mean monthly earnings of Palestinians that reside in Gaza by $18.8 \%$.

Fixed-effects estimates also reveal that a one standard deviation increase in the proportion of work days lost during a quarter due to closures of the West Bank and Gaza Strip (roughly a doubling in the mean proportion of work days lost over the sample period), reduces the employment rate of Palestinians from the West Bank in Israel by 3.8 percentage points. The corresponding estimate for Palestinians from Gaza is 1.9 percentage points. A one standard deviation increase in temporary closures thus reduces the Palestinian employment rate in Israel by 5.7 percentage points. The same increase in the proportion of work days lost due to closures reduces the mean monthly earnings of 
Palestinians from the West Bank by $2.5 \%$, and the mean monthly earnings of Palestinians from Gaza by $1.1 \%$.

The estimated employment and earnings effects of temporary closures and foreign workers suggest that the Israeli-Palestinian conflict leads to substantially worse labor market outcomes for Palestinians both in the short-run and in the long-run. The impact of foreign workers is relatively stronger than the impact of temporary closures because the former more closely corresponds to a permanent, long-run labor substitution effect. The closure effect captures only a transitory short-run restriction on Palestinian labor supply. However, the two effects are not independent. Foreign workers become increasingly more attractive over time as permanent substitutes for Palestinians as temporary closures lead to short-term but frequent Palestinian absenteeism from workplaces in Israel. The foreign worker effect thus picks up to a certain extent the cumulative effect of temporary closures.

It is interesting to note that our estimates not only provide a measure of the labor market costs of a particular political conflict, but can also be put into the context of the literature on the economic consequences of immigration. The history of the Israeli market for unskilled labor is such that Palestinians in the Israeli labor market can be considered natives and overseas foreign workers can be considered recent immigrants. In the immigration literature, it is quite unusual to find significant negative effects of immigrants on the employment and earnings outcomes of natives (see, e.g., Borjas (1987), Card (1990), Altonji and Card (1991), Pischke and Velling (1997), Friedberg 
(2001) and Card (2001)) $)^{3}$. The lack of significant effects is usually attributed to problems associated with appropriately defining competing groups of immigrants and natives, natives responding to immigration by moving their labor and capital to other areas, and immigrants locating in growing local economies (Borjas (2003)).

In this paper, we can reasonably overcome many of these problems. First, we are examining data that relate to two groups of workers that truly compete in the labor market. The Israeli government permitted overseas foreign workers to enter Israel with the explicit intention of replacing Palestinian laborers from the West Bank and Gaza Strip. Second, the PLFS panel data include information on the employment and earnings of individuals that work in the Israeli labor market as well as in the local Palestinian economy, to which they are most likely to move their labor after displacement by foreign workers. Therefore, our estimates suffer less from sample-selection biases that arise when data on the outcomes of displaced individuals are not available (see Card (2001)). Lastly, we can credibly correct for biases due to nonrandom immigration by using government issued foreign worker entry permits as an instrument for the number of foreign workers in the Israeli labor force.

The rest of this paper is organized as follows. The next section describes the PLFS panel data and provides a descriptive analysis of the PLFS as well as the data on foreign workers, foreign worker permits and closures. Section 3 outlines the empirical strategy that we employ. Section 4 discusses the estimation results. In Section 5, we illustrate the extent of sample selection bias that would have arisen had post-displacement data on

\footnotetext{
${ }^{3}$ Borjas (2003) is a notable exception.
} 
Palestinians in the local economies of the West Bank and Gaza Strip not been available. The last section summarizes and concludes.

\section{Data and Descriptive Analysis}

\subsection{Palestinians}

The Palestinian Labor Force Survey (PLFS) of the West Bank and Gaza Strip is administered by the by the Palestinian Central Bureau of Statistics (PCBS). The PLFS began in 1995, following the signing of the Oslo Accords and the creation of the Palestinian Authority (PA). In the PLFS, the same household is investigated 4 times over 6 quarters. Two investigations are conducted during two consecutive quarters and then after a break of two quarters, there are two more consecutive investigations. Households are subsequently dropped from the sample. Each yearly survey round, after 1998, contains approximately 7,600 households with 22,000 individuals aged 15 years and above residing in the West Bank or Gaza Strip. Nomads and persons living in institutions such as prisons or shelters are not included in the survey.

We restrict the sample from the PLFS to males in the labor force between the ages of 18 and 64, and surveyed during the twenty four quarters between quarter one of 1999 and quarter four of 2004. Palestinian women are excluded because their labor force participation rates have traditionally been low, especially in the Israeli labor market. Rounds of the survey prior to 1999 are not considered for several reasons. First, the 
methodology of the sample design was substantially different before 1999. In 1995, the survey was conducted in one quarter only and it was an experimental sample. In 1996, the survey was conducted over three quarters. It wasn't until 1998, after the Palestinian census in 1997, that the survey was conducted in all four quarters of the year. Second, the percentage of individuals that contribute only one quarter of data is $65 \%$ between the years 1995 and 1998 . This is in contrast to $5.6 \%$ percent during the survey years 1999 to 2004. Third, it is currently not possible to link the records of individuals that overlap the survey years 1998 and 1999.

Table 1 presents descriptive statistics on Palestinian employment and earnings outcomes, separately for residents of the West Bank and residents of the Gaza Strip. Column (1) shows a sharply falling employment rate between 1999 and 2004 among residents of both regions. The employment rate among Palestinians from the West Bank fell by 16 percentage points, from a high of .906 in 1999 to .746 in 2004. Note the steep drop in the employment rate from 2000 to 2001. This is a consequence of the second Palestinian uprising which began in September 2000. The employment rate among Palestinians from the West Bank continued to fall after 2001, to a low of .688 in 2002, but began to recover in 2003. The employment rate among Palestinians from Gaza fell by 20 percentage points over the period with a similarly steep decrease from 2000 to 2001, and a modest recovery in 2003. Note that throughout the period, residents of Gaza have employment rates which are approximately ten percentage points lower than residents of the West Bank.

Column (2) displays roughly similar employment rate patterns as in Column (1), after 
further restricting the sample to individuals who report being wage earners (this excludes employers, the self-employed and unpaid family members). Note that there is no clear recovery in the employment rate of wage earners in 2003. Similarly, the employment rate of Palestinian wage earners in $\operatorname{Israel}^{4}$ (Column (3)) decreases nearly monotonically. Among Palestinians from the West Bank, the employment rates in Israel fell from a high of 28 percent in 1999 to a low of 10 percent in 2004. Among Palestinians from Gaza, employment rates in Israel fell from a high of 16 percent in 1999 to a low of 1 percent in 2004.

Columns (4)-(6) of Table 1 report information on monthly earnings regardless of work location, monthly earnings among Palestinians that work in Israel, and the number of days worked per month in Israel among this latter group. A comparison of Columns (4) and (5) reveals that mean monthly earnings among Palestinians that work in Israel are higher than the mean monthly earnings of Palestinians over all work locations. Thus, there is an Israeli labor market earnings premium for both residents of the West Bank and the Gaza Strip. This premium also increases over the sample period (see Angrist (1992, 1995))

In Column (4), it is evident that mean monthly earnings regardless of work location fell between 1999 and 2004 for residents of both the West Bank and the Gaza Strip. Mean earnings are also consistently higher among residents of the West Bank than residents of Gaza throughout the period. In contrast, Column (5) shows that mean monthly earnings of residents of the West Bank who work in Israel slightly increased between 1999 and

\footnotetext{
${ }^{4}$ This includes Palestinians who work in Israeli settlements.
} 
2004. However, this was not the case for Palestinians from Gaza working in Israel. ${ }^{5}$ Residents of the West Bank who worked in Israel also did not experience a decrease in mean days worked in Israel over the period while residents of Gaza did.

Table 2 presents a comparison of background characteristics of Palestinians by region of residence and work location. Columns (1) and (2) show that residents of Gaza are more likely to live in an urban area and a refugee camp than are residents of the West Bank. In terms of marital status, age and years of schooling, the two groups are quite similar. Columns (3) and (4) illustrate that residents of the West Bank who work in Israel are less likely to live in an urban area, are younger, and less educated compared to the population of West Bank residents. Residents of Gaza that work in Israel are more likely to be married and older but less educated than the population of Gaza residents.

The differences in characteristics in Table 2 between Palestinian workers in Israel and the population as a whole, by region, are broadly reflective of Israel's work permit policy for Palestinians and the relatively tighter border controls in Gaza. Including these background characteristics in the regressions will, in fact, help capture the influence of Israel's Palestinian work permit policy, since the issuance of work permits to Palestinians is mostly based on these observed characteristics. To the extent that Palestinian work permits are also a function of unobserved characteristics, which have a direct influence on Palestinian employment outcomes, the effect of foreign worker permits and temporary

\footnotetext{
${ }^{5}$ The monthly earnings of residents of Gaza that work in Israel were higher than the monthly earnings of residents of the West Bank before the onset of the Palestinian uprising in September 2000. This could be due to the relatively larger proportion of Gaza residents working in construction as opposed to agriculture and other employment sectors prior to 2001 (see Table 3 below).
} 
closures will be confounded with Palestinian work permit restrictions since these policies are likely to be correlated. ${ }^{6}$

A defining aspect of Palestinian employment in Israel is its concentration in a small number of employment sectors, and in low skill occupations. The two top panels of Table 3 report Palestinian employment rates over six Israeli employment sectors between 1999 and 2004. Palestinians from the West Bank are concentrated in the construction, manufacturing and hotel sectors in Israel, with the bulk of employment being in construction. Palestinians from Gaza are highly concentrated in construction, manufacturing and agriculture, also with the bulk of employment in construction. ${ }^{7}$

\subsection{Foreign Workers}

The quarterly time series data on the total number of foreign workers in Israel that we use were collected by the Israel Central Bureau of Statistics (ICBS). In constructing the total number of foreign workers (legal and illegal), the ICBS takes into account the date of entry into Israel, the date of exit, and the country of origin of individuals that received work permits or tourist visas. The ICBS measure of the total number of foreign workers thus includes both legal permit holders and illegal immigrants.

\footnotetext{
${ }^{6}$ In the early 1970s, Israel began issuing permits allowing Palestinians residing in the West Bank and Gaza Strip to work in Israel.

${ }^{7}$ Note that residents of Gaza shifted more sharply out of construction and into agriculture and manufacturing than residents of the West Bank after the Palestinian uprising in 2000. This could partially explain why residents of Gaza experienced a decrease in mean monthly earnings in Israel as opposed to residents of the West Bank (see Table 1).
} 
The bottom panel of Table 3 shows the distribution of foreign worker employment in Israel. Note that foreign workers are concentrated in construction, agriculture and services (household services). Thus, there is a substantial overlap in sector of employment in Israel between Palestinians and foreign workers. The overwhelming majority of foreign workers are also employed in low skill occupations. The main mismatch in the employment distribution between Palestinians and foreign workers is in the manufacturing and household services sectors. Nonetheless, Table 3 clearly indicates a substantial amount of competition between the two types of labor input.

It should be noted that in the empirical work that follows, we do not control for sector of employment in Israel because we do not have information on foreign worker permits by employment sector (the instrument), only aggregate numbers of permits in each quarter. As a result, we may be slightly overstating the extent of competition between the two groups due to lack of more detailed data on foreign worker permits. The implication is that our estimated effects of foreign workers on Palestinian employment outcomes are likely to be somewhat conservative, or biased towards zero.

Regarding the total number of foreign workers in Israel, ICBS estimates indicate a relatively small number prior to 1994 . In 1991 , there were only 8,000 foreign workers in the country. In 1994, the number grew to 65,000 and by the end of 1995 , there were about 120,000 . Figure 1 shows that there were approximately 180,000 foreign workers in Israel in the first quarter of 1999 . The number grew to a peak of 240,000 in the first quarter of 2002 and subsequently fell to around 180,000 once again in 2004. The mean 
number of foreign workers over the sample period is 203,500 (with a standard deviation of 22,750$)$.

Interestingly, the mean of 203,500 total foreign workers in Israel over the sample period can be decomposed into 131,500 illegal foreign workers and only 72,000 legal foreign workers (permit holders). According to data supplied to us by the Israel Ministry of Labor and Social Affairs, the mean number of permits issued over the sample period is 80,140 (with a standard deviation of 12,370 ), which exceeds the mean number of legal foreign workers. The relatively high proportion of illegal foreign workers in the Israeli labor market is generally thought to be a consequence of the wage premium that illegal foreign workers can capture in the informal market and the relatively low risk of deportation. Permit holders become illegal foreign workers when their permits are not renewed after expiration (permit length is usually two years) and they do not leave the country. They also become illegal when they accept employment with an employer other than the employer to whom the work permit was originally issued. ${ }^{8}$

It is important to note that the allocation of foreign worker permits by the Israel Ministry of Labor and Social Affairs to Israeli employer associations is periodically reviewed by the Israel State Comptroller's Office. In establishing the number of permits as an exogenous instrument for the number of foreign workers, we rely on these State

\footnotetext{
${ }^{8}$ In 2002, in the agricultural sector, most legal foreign workers are from Thailand. In the construction sector, most legal foreign workers are from Romania, the former USSR, China, Turkey, Bulgaria and Thailand. Illegal foreign workers tend to originate from Romania, Philippines, India, Sri Lanka, Burma, Bulgaria, Hungary, Poland, the former USSR, South America, Africa, Jordan, China, Turkey and Thailand (see www.kavlaoved.org.il/workers/data en.asp). Unfortunately, these data are not comprehensive enough to be fruitfully included in estimation.
} 
Comptroller reports. The reports regularly point to hundreds of deficiencies in the foreign worker permit allocation process.

For example, Israeli employers often file more employment requests than the market requires leading to delays in issuance that can last many months. There is also a lack of computerization and coordination between different authorities within the Ministry. These problems have led to work permits being issued for already finished construction projects, for projects that are not allowed to begin because of lack of proper building permits, and for planned harvests that are based on unverified reports by farmers. These rather well-documented lags and inefficiencies in the permit allocation process provide us with a source of exogenous variation in the total number of foreign workers present in the Israeli labor market.

In Figure 1, we present graphical evidence on the relevance of our instrument. Figure 1 suggests a strong correlation between the number of permits issued each quarter and the total number of foreign workers. It is also clear that there is a sharp increase in the number of foreign worker permits issued, as well as total number of foreign workers in the Israeli labor market, following the beginning of the Palestinian uprising in the fourth quarter of 2000. Note the large drop in the number of Palestinians working in Israel (adjusted by PLFS sampling weights) in the fourth quarter of 2000, which never recovers to pre-uprising levels. ${ }^{9}$

\footnotetext{
${ }^{9}$ The number of Palestinian laborers in Israel falls from a high of 140,000 just prior to the start of the uprising, to around 50,000 in the fourth quarter of 2004. The mean number of Palestinians in the Israeli
} 


\subsection{Temporary Closures of the West Bank and Gaza Strip}

In December 1987, when the first Palestinian uprising broke out, Israel imposed occasional closures on the West Bank and Gaza Strip which made it difficult for Palestinians to reach work locations in Israel. In 1991, with the start of the first Gulf War, Israel closed off the West Bank more consistently and for relatively longer periods of time. Israel continued to impose temporary closures on the West Bank and Gaza Strip subsequent to the first Gulf War, concomitant with surges, or expected surges, in the Israeli-Palestinian conflict.

Our data on temporary closures of the West Bank and Gaza strip were supplied by the Office of the United Nations Special Coordinator (UNSCO) in Ramallah. UNSCO was established in June 1994 following the signing of the Oslo Accords. The mission of UNSCO is to aid in the transition process and strengthen UN inter-agency cooperation to meet the financial, technical, economic and other needs of the Palestinian people.

UNSCO provided us with data on the number of days of external closures imposed by Israel on the West Bank and Gaza Strip in each quarter between 1999 and 2004. External closures consist of restrictions on the movement of Palestinians and Palestinian goods between the West Bank, Gaza, and Israel (as well as third countries). UNSCO does not provide data on the number of days of internal closures. Internal closures restrict the movement of Palestinians and Palestinian goods within the West Bank and Gaza Strip.

labor market over the period is 79,200 with a standard deviation of 39,600. 
Figure 2 plots the UNSCO data on the number of days of comprehensive closures and the number of days of effective closures in each quarter between 1999 and 2004. UNSCO calculates the number of days of effective closures by netting out of comprehensive closures Saturdays, half the number of Fridays (labor and commercial flows are at about half their normal workday level on Fridays) and universally-celebrated Jewish and Muslim holidays. Figure 2 shows that closures were relatively infrequent between 1999 and the start of the second Palestinian uprising. In the fourth quarter of 2000 , there is a dramatic increase in the number of days of closure, which fluctuates with a rather high variance throughout the rest of the sample period. The strong economic growth in the region and the low level and relative constancy of closures before the second Palestinian uprising, strongly suggests that closures can be considered exogenous to the unobserved determinants of Palestinian labor market outcomes.

In the estimations that follow, we measure the frequency of closures each quarter by the "proportion of potential work days lost". That is, we divide the number of days of effective closures by the number of potential work days in the quarter. Over the sample period, the mean number of days of effective closures is 21.44 . The mean number of potential work days (which also excludes Saturdays, half the number of Fridays and Jewish and Muslim holidays) is 69.21. The resulting mean proportion of potential work days lost is .31 (with a standard deviation of .32.)

\section{Estimation Strategy}


The empirical model we use to measure the effect of foreign workers and closures on Palestinian employment outcomes is

$$
\mathrm{Y}_{\mathrm{it}}=\alpha_{0}+\alpha_{1} \mathrm{~F}_{\mathrm{t}}+\alpha_{2} \mathrm{C}_{\mathrm{t}}+\boldsymbol{\beta} \mathbf{X}_{\mathbf{i t}}+\varepsilon_{\mathrm{it}} \text {, }
$$

where $Y_{\text {it }}$ is the employment outcome of individual $\mathbf{i}$ in quarter $\mathbf{t}$. $Y_{\text {it }}$ is either a dummy indicating employment in Israel or the natural logarithm of monthly earnings. $F_{t}$ is the total number of foreign workers in Israel in quarter $\mathbf{t}$ and $\mathrm{C}_{\mathrm{t}}$ is the proportion of work days lost in quarter $\mathbf{t}$ due to closures. Note that including $\mathrm{C}_{\mathrm{t}}$ helps separate short-run lack of access to the Israeli labor market and long-term replacement by foreign workers. The vector $\mathbf{X}_{\mathbf{i t}}$ includes years of schooling, age and age squared, as well as dummies indicating marital status, residence in an urban area, and residence in a refugee camp. ${ }^{10}$ Also included in $\mathbf{X}_{\mathbf{i t}}$ are unrestricted quarterly and year effects. $\varepsilon_{i t}$ is the error term. Estimation of (1) is performed separately for residents of the West Bank and residents of the Gaza Strip.

In addition to estimating (1) by OLS, IV estimation of (1) is performed using the cumulative number of foreign worker permits issued as an instrument for the total number of foreign workers. The first stage in two-stage least squares estimation of (1) is thus,

\footnotetext{
${ }^{10}$ These background characteristics are, to varying degrees, endogenous regressors. Unfortunately, we do not have additional valid instruments that could be used to assess the importance of the endogeneity problem here. As mentioned previously, inclusion of the background characteristics helps control for Israel's Palestinian work permit policy.
} 


$$
\mathrm{F}_{\mathrm{t}}=\pi_{0}+\pi_{1} \mathrm{P}_{\mathrm{t}}+\pi_{2} \mathrm{C}_{\mathrm{t}}+\pi_{3} \mathbf{X}_{\mathbf{i t}}+\xi_{\mathrm{it}}
$$

where $P_{t}$ is the cumulative number of foreign worker permits issued through quarter $t$, since 1991. We use the number of permits issued in 1991 as an initial condition because it is the first year of data on permits at our disposal. ${ }^{11}$

The error term in (2), $\xi_{\mathrm{it}}$, is likely to be correlated with $\varepsilon_{\mathrm{it}}$ in (1) because both error terms contain factors related to labor demand, and other macroeconomic factors, in Israel and the surrounding region. ${ }^{12}$ For example, growth in the region as a whole could lead to voluntary movement of Palestinian laborers back into the local economies of the West Bank and Gaza Strip, and simultaneous increased entry of illegal foreign workers into the Israeli labor market. The exogeneity of $\mathrm{P}_{\mathrm{t}}$ rests on the assumption that administrative lags and inefficiencies in the issuance of foreign worker permits leads to "random" permit issuances. $\mathrm{P}_{\mathrm{t}}$ will also not be perfectly correlated with $\mathrm{F}_{\mathrm{t}}$ because of the availability of illegal foreign labor.

Because the random error component in (1) might contain unobserved individual effects that are potentially correlated with the number of foreign workers in Israel, $\varepsilon_{\mathrm{it}}$ could be further specified as

\footnotetext{
${ }^{11}$ See Friedberg and Sauer (2003) for a similar empirical analysis of the effect of foreign workers in Israel, between the years 1991 and 1995, on Palestinian employment outcomes. Friedberg and Sauer (2003) use ICBS data on Palestinians, as opposed to PCBS data, which are much less reliable. The ICBS ceased collecting data on Palestinians in the West Bank and Gaza Strip in 1995.

${ }^{12}$ Observed proxies for the total demand for foreign workers and Palestinians (such as aggregate Israeli wages or GDP per capita) are not directly included in estimation because they are potentially strongly
} 
where $\mu_{\mathrm{i}}$ captures unobserved characteristics of Palestinian laborers that are fixed over time, and $v_{\text {it }}$ is an independent and identically distributed disturbance term.

Possible individual effects in this context are productivity, motivation, language ability, geographical proximity to work locations inside Israel (assuming no residential mobility), sector of employment in Israel and previous work experience in Israel (unobserved initial conditions). Palestinian workers that are more productive, more motivated, have better Hebrew language skills, that are closer geographically to work locations in Israel, that work in employment sectors less amenable to foreign worker penetration, and that have longer work histories in Israel may be differentially more employable in Israel and less substitutable with foreign workers. These Palestinian laborers should be less affected by the total number of foreign workers in the Israeli labor force than others. The potential importance of these individual effects motivates estimation of (1) by fixed-effects regression. $^{13}$

\section{Estimation Results}

\subsection{Palestinian Employment in Israel}

\footnotetext{
endogenous and noisy proxies.

${ }^{13}$ Explicitly including dynamic considerations in (1), such as lagged employment status, would lead to a potentially severe missing data problem. This is a consequence of the sampling frame of the PLFS which skips two quarters. Thus, the data limit our ability to examine issues of state-dependence vs. unobserved
} 
Table 4 presents estimates of the linear probability model for working in Israel described in the previous section. OLS estimates of the coefficient on foreign workers in Column (1) indicate rather weak in magnitude but statistically significant effects on Palestinians from both the West Bank and Gaza Strip. The coefficient of -.0007 in the top panel implies that an increase of 20,000 foreign workers, which is equivalent to a $10 \%$ increase in supply (or a one standard deviation increase in the mean number of foreign workers over the sample period), reduces the employment rate of Palestinians from the West Bank in Israel by 1.4 percentage points. For Palestinians from Gaza, the employment rate in Israel is reduced by 1 percentage point.

IV estimates of the effect of foreign workers in Column (3) are much stronger than OLS estimates and are statistically significant. Note that the first stage estimates in Column (2) indicate that the permit instrument is highly relevant in both sub-samples. The fixedeffects coefficients on foreign workers in Column (4) are not substantially different from OLS estimates. However, fixed-effects estimates in Column (6), which exploit the permit instrument, yield the strongest estimated impact of foreign workers.

The IV fixed-effects coefficient of -.0086 in the top panel of Column (6) is very precisely estimated and implies that an increase of $10 \%$ in the supply of foreign workers reduces the employment rate of Palestinians from the West Bank in Israel by 17.2 percentage points. Since the size of the wage earner labor force in the West Bank in 1999 is 370,319, a reduction of 17.2 percentage points in the employment rate translates into 63,695 less Palestinians from the West Bank working in Israel for every 20,000 additional foreign heterogeneity. 
workers.

This rather large substitution rate, roughly three fewer Palestinians from the West Bank working in Israel for each additional foreign worker, could be due to the following. First, Palestinians workers may have a substantially decreased incentive to actively search for employment in Israel as foreign workers enter in large numbers and depress wage offers, or cause a change in job tasks and working conditions. Second, it is commonly believed that foreign laborers work much longer days than Palestinians. This is because Palestinians commute to their jobs in Israel in the morning and return to the West Bank (or Gaza) by late afternoon. In contrast, legal foreign workers are permitted to reside in Israel, and many foreign workers in construction and agriculture actually live on the work site.

The IV fixed-effects coefficient of -.0062 in the bottom panel of Column (6) is also very precisely estimated and implies that an increase of $10 \%$ in the supply of foreign workers reduces the employment rate of Palestinians from the Gaza Strip by 12.4 percentage points. This reduction in the employment rate corresponds to 21,350 fewer Palestinians from Gaza working in Israel (the size of the wager earner labor force in Gaza in 1999 is $172,715)$, or a substitution rate of roughly one to one. The smaller effect of foreign workers on residents of Gaza could be due to lower reservation wages among Gaza residents. Lower reservation wages, compared to Palestinians from the West Bank, could arise as alternative employment opportunities in Gaza are considerably more limited. 
Overall, the results suggest that an increase of $10 \%$ in the supply of foreign workers in Israel reduces the employment rate of Palestinians from the West Bank and Gaza Strip in Israel by 29.6 percentage points. This is equivalent to four fewer Palestinians working in Israel for each additional foreign worker. Three quarters of the reduction in Palestinian employment in Israel derives from reduced employment rates among Palestinians from the West Bank.

Table 4 also reports the effect of temporary closures on the employment rates of Palestinians. IV and IV fixed-effects estimates of the impact of closures are not very different from that which is obtained by OLS. The IV fixed-effects estimate in Column (6) of -..1256 is statistically significant and implies that a one standard deviation increase (or doubling) of the frequency of closures, from roughly one-third of potential work days lost to two-thirds of potential work days lost in a quarter, decreases the employment rate of Palestinians from the West Bank in Israel by 3.8 percentage points. The IV fixedeffects coefficient in Column (6) of -.0618 is also precisely estimated and implies that a one standard deviation in the frequency of closures reduces the employment rate of Palestinians from Gaza in Israel by 1.9 percentage points.

The employment rate effects of temporary closures are less straight-forward to interpret, in terms of the decrease in the number of Palestinians working in Israel, since closures are temporary and Palestinian laborers can return to work once the closures are lifted. Controlling for the frequency of closures is, however, essential because otherwise the foreign worker effect would be confounded with short-term, transitory restrictions on 
Palestinian labor supply. Once the direct, transitory impact of closures is controlled for, the foreign worker effect also more cleanly picks up the cumulative, permanent impact of temporary closures. The permanent effect works through the long-term substitution of foreign workers for Palestinians, which is partially a result of Palestinian absenteeism due to closures.

\subsection{Palestinian Monthly Earnings}

Table 5 presents estimates of a log-linear model of Palestinian monthly earnings determination. OLS estimates of the impact of foreign workers on the monthly earnings of Palestinians from the West Bank are not significantly different from zero. However, IV estimates, both with and without fixed effects, are precisely estimated and nonnegligible in magnitude. The first stage estimates again indicate that the permit instrument is highly relevant.

The IV fixed effects estimate of -0.0053 in Column (6) implies that a $10 \%$ increase in the supply of foreign workers (a one standard deviation increase) reduces the mean monthly earnings of Palestinians from the West Bank by $10.6 \%$. The corresponding estimate for Palestinians from Gaza is -.0094 , or a reduction in mean monthly earnings of $18.8 \%$. The larger impact of foreign workers on the mean monthly earnings of Palestinians from Gaza is consistent with the weaker impact of foreign workers on this latter group's employment rate in Israel. That is, relatively worse employment opportunities in the local economy of the Gaza Strip generate lower reservation wages for working in Israel and 
larger earnings losses due to displacement from the Israeli labor market.

The IV fixed effects estimate of -.0819 in Column (6) implies that a doubling of the frequency of closures (a one standard deviation increase) reduces the mean monthly earnings of Palestinians from the West Bank by $2.5 \%$ The corresponding estimate of .0355 for Palestinians from Gaza yields a reduction in mean monthly earnings of $1.1 \%$. Both of these coefficients are precisely estimated but are small in magnitude. As in the case of the effect of closures on employment rates in Israel, the direct, transitory impact of closures on mean monthly earnings is much weaker than the permanent impact of closures and long-run substitution by foreign workers.

\subsection{Additional Results}

Several additional estimation results, not displayed in Tables 4 and 5 for sake of brevity, are worthy of mention. Among Palestinians from the West Bank, IV fixed-effects estimates of the linear probability model indicate that all background characteristics, except residing in an urban area (which has a positive effect), are not significantly different from zero. All quarter and year effects in this model are highly significant. In the log-linear model of monthly earnings determination for Palestinians residing in the West Bank, IV fixed-effects estimates yield significant schooling, age, quarter and year effects. However, an extra year of schooling increases mean monthly earnings by only one-third of one percent. The estimated coefficients on age and age-squared are more substantial (the estimated coefficient on age is .048, and on age-squared it is -.0005). 
In the linear probability model for Palestinians from Gaza, IV fixed-effects estimates yield significant marital status, age, quarter and year effects. Older and married Palestinians from Gaza are more likely to be employed in Israel, reflecting Israel's Palestinian work permit policy and tighter border controls in Gaza. In the log-linear model of monthly earnings determination, IV fixed-effects estimates yield significant schooling, age, marital status, quarter and year effects. The estimated return to schooling of $2.4 \%$ is much higher than for Palestinians from the West Bank, as is the marriage premium of $3.6 \%$, and the concavity of the age-earnings profile (the coefficients on age and age-squared are .058 and -.0006 , respectively). These additional results are consistent with earlier findings on the impact of background characteristics on Palestinian employment in Israel and Palestinian earnings using ICBS data on Palestinians (see Angrist $(1992,1995,1996,1998)$ and Yashiv (2004)). ${ }^{14}$

\section{The Importance of Post-Displacement Earnings Information}

In most studies of the impact of immigration on the earnings of natives, information on the employment outcomes of natives after displacement by immigrants is not available. In this section, we simulate this common situation by restricting the sample to only Palestinians who are working in Israel. That is, the observed earnings information for many of these individuals who subsequently work in the local Palestinian economy is not

\footnotetext{
${ }^{14}$ IV random-effects estimates are not systematically different from IV fixed-effects estimates. Hausman tests suggest that the fixed-effects strategy is preferable. Additional specifications show that there are no important nonlinearities in the effect of foreign workers and closures and very few significant interaction terms with background characteristics.
} 
included in estimation, as it is in Table 5. This produces a selected sample and allows an assessment of the contribution of our post-displacement earnings data. In other words, we can quantify the extent of sample selection bias that would have arisen had the PCBS data set not been so rich. We perform this exercise only for Palestinians from the West Bank since the resulting sample size for Palestinians from Gaza is rather small. ${ }^{15}$

The IV fixed-effects estimate of the impact of foreign workers in Column (6) of Table 6, in the sample restricted to workers in Israel only, is .0058 and is not precisely estimated (the standard error is .0041). The results suggest that there is no significant change in mean earnings with the influx of foreign workers. This is in sharp contrast to the precisely estimated coefficient on foreign workers of -.0053 in Column (6) of Table 5, which uses the earnings data in both economies. Thus, sample selection substantially biases upward the effect of "immigrants" on "natives" in this context, and substantially biases downward the labor market costs of the conflict. Note that the estimated effect of foreign workers is positive regardless of estimation technique (OLS, IV or fixed-effects).

Regarding the effect of closures on mean monthly earnings, the IV fixed-effects estimate of the impact of closures in the restricted sample remains significantly negative, as in the unrestricted sample. However, the estimated coefficient on closures in Table 6 is less negative than the corresponding estimate in Table 5. In the restricted sample, the estimated coefficient on closures is -.0819 . In the unrestricted sample it is -.0640. In this case as well, sample selection leads to a substantial bias, or underestimate of the labor

\footnotetext{
${ }^{15}$ As an indication of the sample size problem for Gaza, see Table 1, which shows that less than 3 percent of Palestinians are employed in Israel in each year after 2001.
} 
market costs of the conflict deriving from temporary closures.

\section{Conclusion}

In this paper, we contribute to the literature on the economic costs of political instability by measuring the consequences of the Israeli-Palestinian conflict for Palestinian employment and earnings. We quantify the conflict by the frequency of temporary closures of the West Bank and Gaza Strip and the number of overseas foreign workers in the Israeli labor market. Data on Palestinian employment and earnings outcomes are taken from the PLFS of the PCBS. We combine the PLFS panel data with quarterly time series data on the number of foreign workers in Israel, the number of foreign worker permits issued to Israeli employers, and the frequency of temporary closures of the West Bank and Gaza Strip, between the years 1999 and 2004.

Fixed-effects estimates that exploit the number of foreign workers permits issued each quarter by the Israeli government as an instrument for the number of foreign workers, yield large and statistically significant effects of the conflict on Palestinian employment rates in Israel and mean monthly earnings. We find that an increase of $10 \%$ in the supply of foreign workers, or a one standard deviation increase in supply, reduces the employment rate of Palestinians from the West Bank in Israel by 17.2 percentage points and the employment rate of Palestinians from Gaza in Israel by 12.4 percentage points. A one standard deviation increase in the supply of foreign workers reduces the mean monthly earnings of Palestinians that reside in the West Bank by $10.6 \%$ and the mean 
monthly earnings of Palestinians that reside in Gaza by $18.8 \%$.

IV fixed-effects estimates also indicate that a one standard deviation increase in the proportion of work days lost during a quarter due to closures of the West Bank and Gaza Strip (roughly a doubling in the mean proportion of work days lost over the sample period), reduces the employment rate of Palestinians from the West Bank in Israel by 3.8 percentage points, and the employment rate of Palestinians from Gaza by 1.9 percentage points. A one standard deviation increase in the proportion of work days lost due to closures reduces the mean monthly earnings of Palestinians from the West Bank by $2.5 \%$, and the mean monthly earnings of Palestinians from Gaza by $1.1 \%$. The impact of foreign workers is relatively stronger than the impact of temporary closures because the former more closely corresponds to a permanent, long-run labor substitution effect, while the latter captures a transitory, short-run restriction on Palestinian labor supply. Note, however, that the long-run labor substitution away from Palestinians is also a consequence of temporary closures.

Our study also contributes to the immigration literature. We are able to overcome many of the problems associated with not being able to find significant negative effects of immigrants on the employment and earnings of natives. In the Israeli market for unskilled labor, Palestinians can be considered natives and foreign workers recent immigrants. Identification of the effect of immigrants on natives in this case rests on the fact that Palestinians and foreign workers truly compete in the Israeli labor market, the PLFS panel data include information on the employment and earnings of Palestinians in the 
local economies of the West Bank and Gaza Strip after displacement by foreign workers in Israel, and we have what we believe is a credible instrument to correct for biases due to non-random immigration. 


\section{References}

Abadie, A., and J. Gardeazabal (2003), "The Economic Costs of Conflict," American Economic Review, 93(1), 113-132.

Alesina, A., and R. Perotti (1996), "Income Distribution, Political Instability and Investment," European Economic Review, 40, 1203-1228.

Altonji, J.G., and D. Card, "The Effects of Immigration on the Labor Market Outcomes of Less-Skilled Natives," in John M. Abowd and Richard B. Freeman, eds., Immigration, Trade, and the Labor Market (Chicago: University of Chicago Press, 1991).

Angrist, J.D. (1992), "Wages and Employment in the West Bank and the Gaza Strip: 1981-1990,” Falk Institute for Economic Research in Israel Discussion Paper No. 92.02, Hebrew University, Jerusalem, July 1992.

Angrist, J.D. (1995), “The Economic Returns to Schooling in the West Bank and Gaza Strip,” American Economic Review, 85, 1065-1087.

Angrist, J.D. (1996), “Short-run Demand for Palestinian Labor,” Journal of Labor Economics, 14, 425-453.

Angrist, J.D. (1998), "The Palestinian Labor Market Between the Gulf War and 
Autonomy,"' MIT Department of economics, Working Paper 98-5, May 1998.

Angrist, J.D., and A.D. Kugler (2004), “Coca, Conflict, and Rural Income: Evidence from Colombia," unpublished manuscript.

Barro, R.J. (1991), "Economic Growth in a Cross Section of Countries," Quarterly Journal of Economics, 106(2), 407-443.

Berman, E., and D.D. Laitin (2005), "Hard Targets: Theory and Evidence on Suicide Attacks,” NBER Working Paper 11740.

Berrebi, C., and E.F. Klor (2005), "On Terrorism and Electoral Outcomes: Theory and Evidence from the Israeli-Palestinian Conflict," unpublished manuscript.

Borjas, G.J. (1987), “Immigrants, Minorities, and Labor Market Competition,” Industrial and Labor Relations Review, 25, 382-392.

Borjas, G.J. (2003), “The Labor Demand Curve is Downward Sloping: Reexamining the Impact of Immigration on the Labor Market," Quarterly Journal of Economics, 118(4), $1335-1376$.

Card, D. (1990), "The Impact of the Mariel Boatlift on the Miami Labor Market," Industrial and Labor Relations Review, 28, 245-257. 
Card, D. (2001), "Immigrant Inflow, Native Outflows, and the Local Labor Market Impacts of Higher Immigration,” Journal of Labor Economics, 19, 22-64.

Eckstein, Z., and D. Tsiddon (2004), "Macroeconomic Consequences of Terror: Theory and the Case of Israel”, Journal of Monetary Economics, 51(5), 971-1002.

Friedberg, R.M. (2001), "The Impact of Mass Migration on the Israeli Labor Market," Quarterly Journal of Economics, 116, 1373-1408.

Friedberg, R.M., and R.M. Sauer (2003), “The Effects of Foreign Guest Workers in Israel on the Labor Market Outcomes of Palestinians from the West Bank and Gaza Strip,” The Maurice Falk Institute for Economic Research in Israel, Discussion Paper No. 03.08.

Jaeger, D.A., and D.M. Paserman (2005), "The Cycle of Violence? An Empirical Analysis of Fatalities in the Palestinian-Israeli Conflict," IZA Discussion Paper No. 1808.

Mauro, P. (1995), “Corruption and Growth,” Quarterly Journal of Economics, 110(3), 681-712.

Pischke, J., and J. Velling, "Employment Effects of Immigration to Germany: An Analysis Based on Local Labor Markets," Review of Economics and Statistics, 79, 594604. 
Venieris, Y.P., and D.K. Gupta (1986), "Income Distribution and Sociopolitical Instability as Determinants of Savings: A Cross-Sectional Model," Journal of Political Economy, 94(4), 873-883.

Yashiv, E. (2004), "Positive or Negative? Migrant Workers Self Selection Revisited," IZA Discussion Paper No. 1094. 
Table 1

\section{Descriptive Statistics \\ Palestinian Employment and Earnings Outcomes}

$\begin{array}{ccccccc}\text { Employed } & \begin{array}{c}\text { Employed } \\ \text { Wage }\end{array} & \begin{array}{c}\text { Employed } \\ \text { Wage }\end{array} & \begin{array}{c}\text { Monthly } \\ \text { Earnings }\end{array} & \begin{array}{c}\text { Monthly } \\ \text { Earnings }\end{array} & \begin{array}{c}\text { Days } \\ \text { Worked }\end{array} & \text { Sample } \\ \text { Earners } & \text { Earners } & \text { (NIS) } & \text { In Israel } & \text { per } & \\ & & \text { in Israel } & & \text { (NIS) } & \text { Month } & \\ & & & & & \text { in Israel }\end{array}$
Year
(1)
(2)
(3)
(4)
(5)
(6)

Residents of the West Bank

$\begin{array}{lccccccc}1999 & .906 & .694 & .275 & 1,486 & 1,695 & 19.8 & 20,524 \\ & & & & (816) & (767) & (5.1) & \\ 2000 & .871 & .678 & .236 & 1,494 & 1,693 & 19.4 & 20,807 \\ & & & & (795) & (718) & (4.8) & \\ 2001 & .756 & .603 & .156 & 1,290 & 1,450 & 18.7 & 18,619 \\ & & & & (549) & (623) & (6.4) & \\ 2002 & .688 & .570 & .102 & 1,360 & 1,737 & 20.2 & 14,496 \\ & & & & (646) & (896) & (6.5) & \\ 2003 & .740 & .552 & .104 & 1,294 & 1,758 & 20.1 & 18,055 \\ & & & & (854) & (908) & (6.4) & \\ 2004 & .746 & .553 & .098 & 1,312 & 1,780 & 20.1 & 17,656 \\ & & & & (897) & (1,236) & (6.1) & \end{array}$

Residents of the Gaza Strip

\begin{tabular}{|c|c|c|c|c|c|c|}
\hline 1999 & .823 & .741 & .159 & $\begin{array}{l}1,299 \\
(845)\end{array}$ & $\begin{array}{l}1,933 \\
(685)\end{array}$ & $\begin{array}{l}20.2 \\
(3.3)\end{array}$ \\
\hline 2000 & .809 & .744 & .132 & $\begin{array}{l}1,261 \\
(809)\end{array}$ & $\begin{array}{l}1,893 \\
(712)\end{array}$ & $\begin{array}{l}20.0 \\
(3.6)\end{array}$ \\
\hline 2001 & .643 & .688 & .013 & $\begin{array}{l}1,130 \\
(473)\end{array}$ & $\begin{array}{c}805 \\
(482)\end{array}$ & $\begin{array}{l}16.6 \\
(5.2)\end{array}$ \\
\hline 2002 & .598 & .644 & .017 & $\begin{array}{l}1,124 \\
(664)\end{array}$ & $\begin{array}{l}1,427 \\
(902)\end{array}$ & $\begin{array}{l}18.0 \\
(5.3)\end{array}$ \\
\hline 2003 & .702 & .632 & .026 & $\begin{array}{l}1,020 \\
(548)\end{array}$ & $\begin{array}{l}1,484 \\
(771)\end{array}$ & $\begin{array}{l}17.9 \\
(4.3)\end{array}$ \\
\hline 2004 & .628 & .675 & .009 & $\begin{array}{l}1,119 \\
(670)\end{array}$ & $\begin{array}{l}1,627 \\
(871)\end{array}$ & $\begin{array}{l}17.2 \\
(4.8)\end{array}$ \\
\hline
\end{tabular}

Note: Data are drawn from the Palestinian Labor Force Surveys (PLFS) of the Palestinian Central Bureau of Statistics (PCBS). Columns (1) through (6) contain sample proportions and means. Standard deviations for the means are in parentheses. Monthly earnings are in constant $1996 \mathrm{New}$ Israeli Shekels (NIS). In 1996, 1 NIS equals approximately .33 US dollars. 
Table 2

\section{Descriptive Statistics \\ Background Characteristics}

$\begin{array}{cccc}\begin{array}{c}\text { Residents } \\ \text { of the } \\ \text { West Bank }\end{array} & \begin{array}{c}\text { Residents } \\ \text { of Gaza }\end{array} & \begin{array}{c}\text { Residents } \\ \text { of the } \\ \text { West Bank } \\ \text { Working } \\ \text { In Israel }\end{array} & \begin{array}{c}\text { Residents } \\ \text { of Gaza } \\ \text { Working }\end{array} \\ \text { in Israel } \\ \end{array}$
(1)
(2)
(3)
(4)

$\begin{array}{ccccc}\text { Married } & 0.69 & 0.75 & 0.70 & 0.93 \\ \text { Urban } & 0.38 & 0.56 & 0.31 & 0.60 \\ \begin{array}{c}\text { Refugee } \\ \text { Camp }\end{array} & 0.12 & 0.32 & 0.11 & 0.27 \\ \text { Age } & 33.7 & 34.4 & 31.4 & 36.5 \\ & (11.2) & (10.9) & (9.7) & (8.6)\end{array}$

$\begin{array}{ccccc}\text { Years of } & 9.9 & 10.4 & 9.0 & 8.9 \\ \text { Schooling } & (3.8) & (3.9) & (3.0) & (3.4) \\ & & & & \\ \begin{array}{c}\text { Sample } \\ \text { Size }\end{array} & 110,157 & 56,447 & 18,546 & 3,492\end{array}$

Note: Data are drawn from the Palestinian Labor Force Surveys (PLFS) of the Palestinian Central Bureau of Statistics (PCBS). Columns (1) through (4) contain sample proportions and means. Standard deviations for the means are in parentheses. 
Table 3

Palestinian and Foreign Worker Employment in Israel by Sector

\begin{tabular}{|c|c|c|c|}
\hline cultu & Constructio & Manufacturin & $\begin{array}{c}\text { Commerce } \\
\text { Hotels }\end{array}$ \\
\hline
\end{tabular}

\begin{tabular}{|c|c|c|c|c|c|c|}
\hline Year & (1) & (2) & (3) & $(4)$ & $(5)$ & (6) \\
\hline \multicolumn{7}{|c|}{ Residents of the West Bank } \\
\hline 1999 & .073 & .552 & .131 & .144 & .018 & .082 \\
\hline 2000 & .075 & .551 & .123 & .159 & .018 & .074 \\
\hline 2001 & .066 & .506 & .146 & .179 & .018 & .085 \\
\hline 2002 & .075 & .409 & .173 & .208 & .025 & .111 \\
\hline 2003 & .066 & .466 & .154 & .196 & .021 & .098 \\
\hline 2004 & .075 & .410 & .167 & .209 & .029 & .111 \\
\hline \multicolumn{7}{|c|}{ Residents of the Gaza Strip } \\
\hline 1999 & .140 & .603 & .148 & .076 & .011 & .024 \\
\hline 2000 & .179 & .520 & .172 & .090 & .020 & .019 \\
\hline 2001 & .239 & .058 & .566 & .106 & .000 & .032 \\
\hline 2002 & .264 & .391 & .302 & .030 & .014 & .000 \\
\hline 2003 & .190 & .452 & .302 & .049 & .006 & .000 \\
\hline 2004 & .138 & .495 & .270 & .097 & .000 & .000 \\
\hline
\end{tabular}

Foreign Workers

$\begin{array}{lllllll}1999 & .115 & .332 & .012 & .040 & .000 & .502 \\ 2000 & .105 & .309 & .011 & .056 & .000 & .519 \\ 2001 & .099 & .336 & .010 & .063 & .000 & .492 \\ 2002 & .097 & .318 & .011 & .060 & .000 & .514 \\ 2003 & .113 & .268 & .088 & .062 & .000 & .549 \\ 2004 & .135 & .267 & .078 & .060 & .000 & .530\end{array}$

Note: Data on Palestinians are drawn from the Palestinian Labor Force Surveys (PLFS) of the Palestinian Central Bureau of Statistics (PCBS). Data on foreign workers are from the Israel Central Bureau of Statistics (ICBS). Columns (1) through (6) contain row percentages that sum to one. 
Figure 1

Foreign Workers, Foreign Worker Permits, and Palestinian Laborers in Israel

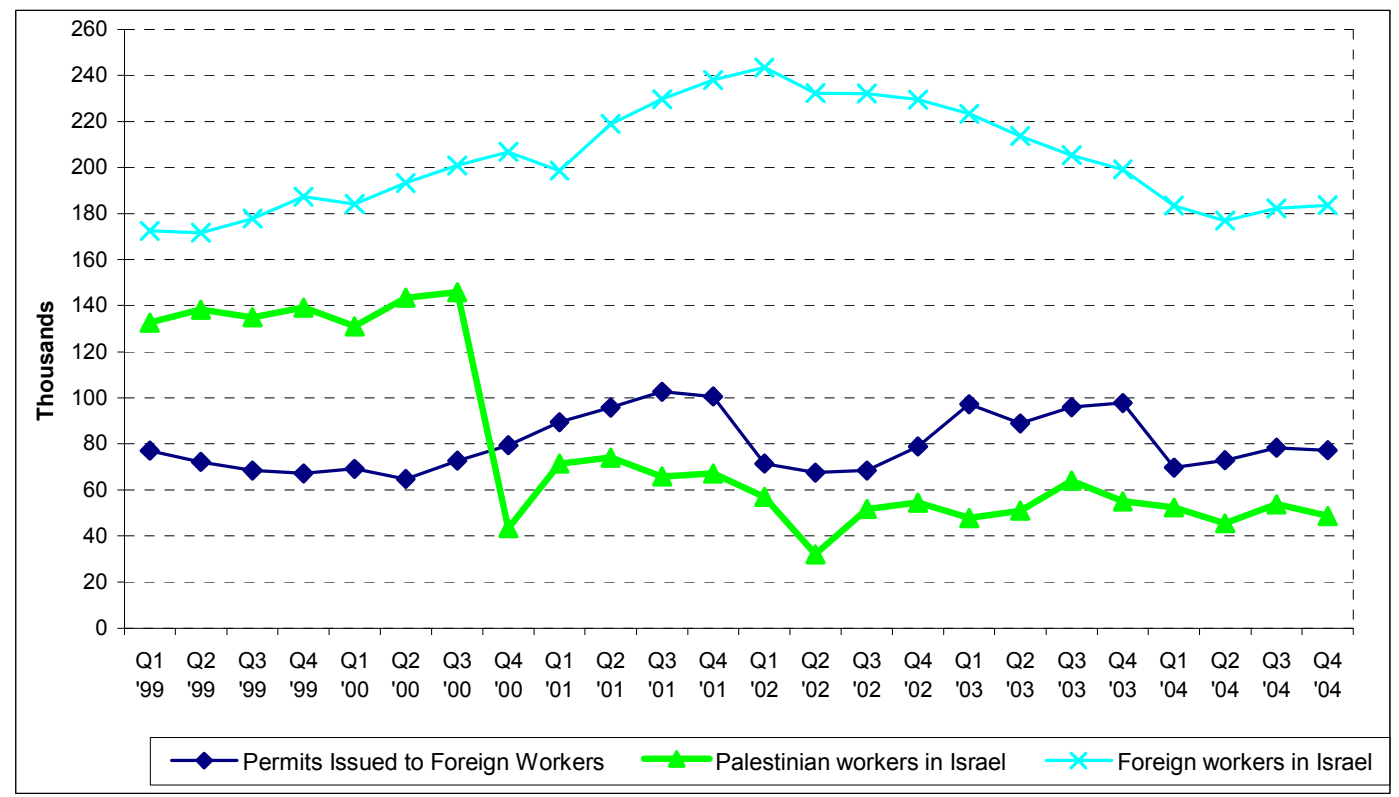

Note: Data are drawn from the PLFS, the ICBS and the Israeli Ministry of Labor. 
Figure 2

\section{Days of Closure of the West Bank and Gaza Strip}

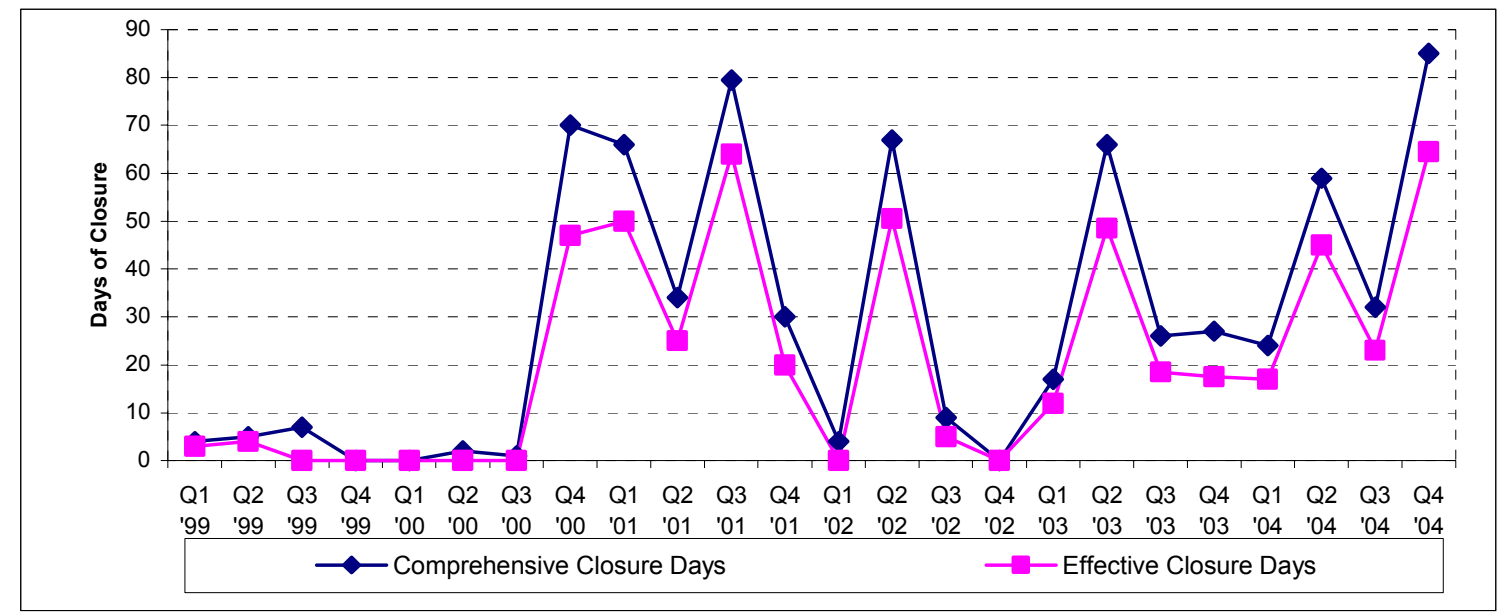

Note: Data come from the United Nations Special Coordinator Office (UNSCO). Effective closure days are comprehensive external closure days after subtracting Saturdays, half the number of Fridays in the quarter and universally-celebrated Jewish and Muslim holidays. 
Table 4

Estimation Results

Palestinian Employment in Israel

\begin{tabular}{|c|c|c|c|c|c|c|}
\hline & OLS & $\begin{array}{l}\text { First } \\
\text { Stage }\end{array}$ & IV & $\begin{array}{c}\text { Fixed } \\
\text { Effects }\end{array}$ & $\begin{array}{l}\text { First } \\
\text { Stage }\end{array}$ & $\begin{array}{c}\text { IV } \\
\text { Fixed } \\
\text { Effects }\end{array}$ \\
\hline \multicolumn{7}{|c|}{ Residents of the West Bank $(\mathrm{N}=110,154)$} \\
\hline & & & & & & \\
\hline \multirow[t]{2}{*}{ Foreign Workers $(1,000 \mathrm{~s})$} & -.0007 & - & -.0065 & -.0006 & - & -.0086 \\
\hline & $(.0001)$ & & $(.0006)$ & $(.0001)$ & & $(.0006)$ \\
\hline \multirow[t]{2}{*}{ Closures } & -.1015 & -1.7289 & -.1073 & -.1012 & -4.2343 & -.1256 \\
\hline & $(.0040)$ & $(.1072)$ & $(.0041)$ & $(.0040)$ & $(.1191)$ & $(.0045)$ \\
\hline \multirow[t]{2}{*}{ Foreign Worker Permits $(1,000 \mathrm{~s})$} & - & .4651 & - & - & .4326 & - \\
\hline & & $(.0066)$ & & & $(.0081)$ & \\
\hline $\mathrm{R}^{2}$ & .0697 & .8626 & .0535 & .0224 & .7210 & .0280 \\
\hline \multicolumn{7}{|c|}{ Residents of the Gaza Strip $(\mathrm{N}=56,446)$} \\
\hline & & & & & & \\
\hline \multirow[t]{2}{*}{ Foreign Workers $(1,000 \mathrm{~s})$} & -.0005 & - & -.0049 & -.0003 & - & -.0062 \\
\hline & $(.0001)$ & & $(.0008)$ & $(.0001)$ & & $(.0008)$ \\
\hline \multirow[t]{2}{*}{ Closures } & -.0604 & -1.2217 & -.0631 & -.0458 & -3.5328 & -.0618 \\
\hline & $(.0030)$ & $(.1507)$ & $(.0032)$ & $(.0033)$ & $(.1733)$ & $(.0045)$ \\
\hline \multirow[t]{2}{*}{ Foreign Worker Permits $(1,000 \mathrm{~s})$} & - & .3947 & - & - & .3013 & - \\
\hline & & $(.0093)$ & & & $(.0125)$ & \\
\hline $\mathrm{R}^{2}$ & .0990 & .8716 & .0769 & .0728 & .8575 & .0724 \\
\hline
\end{tabular}

Note: Estimates are from linear probability models. The dependent variable is a dummy for working in Israel. Data are drawn from the Palestinian Labor Force Surveys (PLFS) of the Palestinian Central Bureau of Statistics (PCBS). Sample includes men aged 18-64 residing in the West Bank and Gaza Strip. Standard errors, in parentheses, are robust and clustered at the individual level. All regressions include years of schooling, age, age-squared, marital status, urban area residence, refugee camp residence, and unrestricted quarter and year effects. 
Table 5

Estimation Results Palestinian Monthly Earnings

\begin{tabular}{|c|c|c|c|c|c|c|}
\hline & OLS & $\begin{array}{l}\text { First } \\
\text { Stage }\end{array}$ & IV & $\begin{array}{l}\text { Fixed } \\
\text { Effects }\end{array}$ & $\begin{array}{l}\text { First } \\
\text { Stage }\end{array}$ & $\begin{array}{c}\text { IV } \\
\text { Fixed } \\
\text { Effects }\end{array}$ \\
\hline \multicolumn{7}{|c|}{ Residents of the West Bank $(\mathrm{N}=49,470)$} \\
\hline & & & & & & \\
\hline \multirow[t]{2}{*}{ Foreign Workers $(1,000 \mathrm{~s})$} & -.0002 & - & -.0066 & -.0001 & - & -.0053 \\
\hline & $(.0003)$ & & $(.0016)$ & $(.0003)$ & & $(.0013)$ \\
\hline \multirow[t]{2}{*}{ Closures } & -.0741 & -2.6254 & -.0850 & -.0659 & -4.7464 & -.0819 \\
\hline & $(.0108)$ & $(.1590)$ & $(.0108)$ & $(.0087)$ & $(.1767)$ & $(.0097)$ \\
\hline \multirow[t]{2}{*}{ Foreign Worker Permits $(1,000 \mathrm{~s})$} & - & .3603 & - & - & .4180 & - \\
\hline & & $(.0089)$ & & & $(.0099)$ & \\
\hline $\mathrm{R}^{2}$ & .1188 & .8761 & .1110 & .0877 & .6639 & .0875 \\
\hline \multicolumn{7}{|c|}{ Residents of the Gaza Strip $(\mathrm{N}=26,644)$} \\
\hline \multirow{3}{*}{ Foreign Workers $(1,000 \mathrm{~s})$} & & & & & & \\
\hline & -.0022 & - & -.0176 & -.0015 & - & -.0094 \\
\hline & $(.0004)$ & & $(.0032)$ & $(.0004)$ & & $(.0021)$ \\
\hline \multirow[t]{2}{*}{ Closures } & -.0420 & -.9573 & -.0475 & -.0108 & -4.2748 & -.0355 \\
\hline & $(.0123)$ & $(.2233)$ & $(.0125)$ & $(.0105)$ & $(.2489)$ & $(.0119)$ \\
\hline \multirow[t]{2}{*}{ Foreign Worker Permits $(1,000 \mathrm{~s})$} & - & .2489 & - & - & .3254 & - \\
\hline & & $(.0127)$ & & & $(.0154)$ & \\
\hline $\mathrm{R}^{2}$ & .2766 & .8737 & .2363 & .2575 & .8379 & 2609 \\
\hline
\end{tabular}

Note: The dependent variable is the log of monthly labor market earnings in Israel and/or the local economy (West Bank or Gaza Strip). Data are drawn from the Palestinian Labor Force Surveys (PLFS) of the Palestinian Central Bureau of Statistics (PCBS). Sample includes men aged 18-64 residing in the West Bank and Gaza Strip. Standard errors, in parentheses, are robust and clustered at the individual level. All regressions include years of schooling, age, age-squared, marital status, urban area residence, refugee camp residence, and unrestricted quarter and year effects. 
Table 6

Estimation Results

Palestinian Monthly Earnings in Israel

\begin{tabular}{|l|c|c|c|c|c|c|}
\hline & OLS & $\begin{array}{c}\text { First } \\
\text { Stage }\end{array}$ & IV & $\begin{array}{c}\text { Fixed } \\
\text { Effects }\end{array}$ & $\begin{array}{c}\text { First } \\
\text { Stage }\end{array}$ & $\begin{array}{c}\text { IV } \\
\text { Fixed } \\
\text { Effects }\end{array}$ \\
\hline \multicolumn{7}{|c|}{ Residents of the West Bank (N=15,316) } \\
\hline & & & & & & \\
\hline Foreign Workers (1,000s) & .0004 & - & .0072 & .0006 & - & .0058 \\
\hline & $(.0006)$ & & $(.0033)$ & $(.0006)$ & & $(.0041)$ \\
\hline & & & & & & \\
\hline Closures & -.0289 & -5.4365 & .0021 & -.0912 & -6.1825 & -.0640 \\
\hline & $(.0225)$ & $(.3042)$ & $(.0254)$ & $(.0209)$ & $(.4199)$ & $(.0310)$ \\
\hline & & & & & & \\
\hline Foreign Worker Permits (1,000s) & - & .3240 & - & - & .2620 & - \\
\hline & & $.0143)$ & & & $(.0230)$ & \\
\hline $\mathrm{R}^{2}$ & & & & & & \\
\hline
\end{tabular}

Note: The dependent variable is the log of monthly labor market earnings in Israel only. Data are drawn from the Palestinian Labor Force Surveys (PLFS) of the Palestinian Central Bureau of Statistics (PCBS). Sample includes men aged 18-64 residing in the West Bank. Standard errors, in parentheses, are robust and clustered at the individual level. All regressions include years of schooling, age, age-squared, marital status, urban area residence, refugee camp residence, and unrestricted quarter and year effects. 